\title{
Model Tests on Use of Tyre Chips and Fly Ash Chips as a Replacement of Aggregate in Stone Columns
}

\author{
V. Naveenraj ${ }^{1, a^{*}}$, P. Kulanthaivel ${ }^{1, b}$, S. Velmurugan ${ }^{3,}$ c, M. Arun Kumar ${ }^{1}, \mathrm{~d}^{*}$ and \\ Prabakaran ${ }^{2, \mathrm{e}}$ \\ ${ }^{1 *}$ Assistant Professor, Department of Civil Engineering, Kongu Engineering College, Perundurai, \\ Erode, Tamil Nadu, India \\ ${ }^{2}$ PG Scholar, Department of Civil Engineering, Kongu Engineering College, Perundurai, Erode, \\ Tamil Nadu, India \\ ${ }^{3}$ Assistant Professor, Department of Civil Engineering, Bannari Amman Institute of Technology, \\ Sathyamangalam, Erode, Tamil Nadu, India

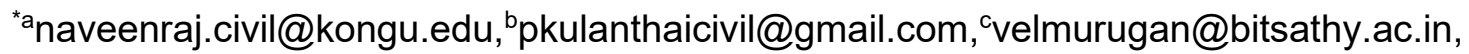 \\ d*rsmanoharun@gmail.com, epraba_27@icloud.com
}

Keywords: Tyre Chips, Fly Ash Brick Chips, Aggregates, Soft Clay, Stone Columns, Load Carrying Capacity, Settlements, Comparison

\begin{abstract}
In order to reduce the generated waste in industry the concept of reusability is adopted as an application in the civil engineering field. In this study, the experiments were performed by using shredded tyre chips, chips of fly ash bricks in partial replacement with aggregates passing through $12.5 \mathrm{~mm}$ sieve and retaining on $10 \mathrm{~mm}$ sieve (IS-Indian standard). The experiments with partial replacement of stone columns were carried out at various proportions of tyre chips and fly ash brick chips in soft clay. Corresponding settlement rate was noted by loading the stone column gradually through a hydraulic jack for various L/D ratios. On comparison the final results it was concluded that the stone column with replacement of $75 \%$ tyre chips and $25 \%$ coarse aggregate proved good to carry maximum load and with lower settlement rate than ordinary stone column without replacement.
\end{abstract}

\section{Introduction}

Tyre chips are one of the major wastes generated from the industries now-a-days which alarms to environmental pollution. As major environmental thread is caused by Land filling and burning of tyres, researches are being undergoing to use the tyre chips in effective manner. From survey of the tyres that were scrapped, $43 \%$ were burnt as tire-derived fuel, with cement manufacturing the largest user, in another $25 \%$ were used to make ground rubber, $8 \%$ were used in civil engineering projects, $17 \%$ were disposed of in landfills and $8 \%$ had other uses In geotechnical engineering perspective the waste tyre chips [1] has low density, high strength, low thermal conductivity, durability, resilience, high frictional strength and hydrophobic nature.

Reviews about the use of scrap tyres, shredded tyres as a soil mixtures and various evaluation of chemical compositions, sorption capacity, environmental sustainability and reusability of waste tyres in geotechnics has been viewed [2]. When coarse aggregate is partially replaced with waste tyre chips and fly ash chips it helps to improve the strength parameter like load bearing capacity and reduce the settlement characteristics of the Clay soil [3]. 


\section{Soil sample collection and tests}

Soil sample for test is collected from Vellode of erode district. The sample is then distorted to certain range from its solidity and the basic tests were carried out in laboratory. Sieve analysis is done for the collected sample for gradation of the soil and it is classified as fine grained soil of size less than $.002 \mathrm{~mm}$ which belongs to Clay type soil[4].

\section{Characteristics of materials used}

\section{Clayey soil}

For the study, the soil is taken as Soft Clay. The various index properties of Soft clay such as moisture content, liquid limit, plasticity [5], specific gravity, density and engineering properties such as compressibility, consolidation [6] was carried out in the laboratory as per the procedures recommended by Indian Standards (IS) Codes. The properties of Soft clay is studied [7] and values are showed in the table 1 .

Table 1. Properties of Soil

\begin{tabular}{|c|c|}
\hline Property of soil & Vellode clay soil \\
\hline Soil Classification & CI \\
\hline Specific Gravity & 2.5 \\
\hline Liquid Limit (\%) & 37 \\
\hline Plastic Limit (\%) & 16 \\
\hline Plastic Index (\%) & 21 \\
\hline
\end{tabular}

\section{Tyre chips}

Radial tyre is used for taking the tyre chips for the experiments shown in Figure1. The scaling Factor used in test is $1 / 10$.Tyre chips which passes through $12.5 \mathrm{~mm}$ sieve and retains on $10 \mathrm{~mm}$ sieve as per IS codes was taken [8]. The properties of Tyre chips is showed in the table 2. Various tests for tyre chips has been carried in laboratory such as water absorption, tensile strength, compression and Specific gravity. For carrying the test with soft clay, various comparative study has been made through the existing researches and experiments [9].Thus the usage of tyre chips not only reduces the waste but it also helps in saving the natural resources, energy and to increase the stability of soft soil[1].

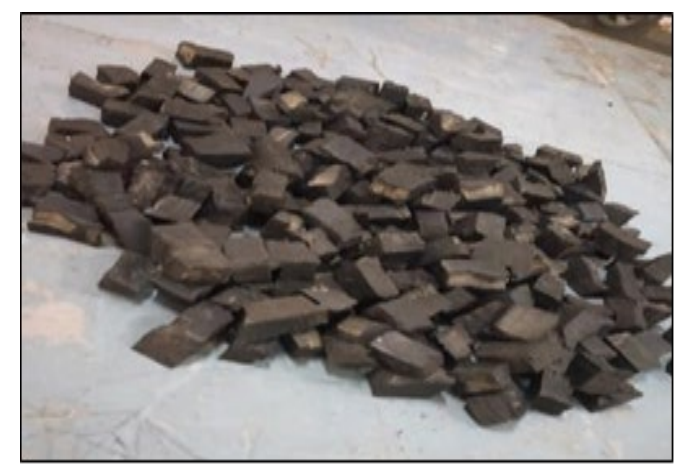

Figure 1. Tyrechips 


\section{Table2. Tyrechipsproperties}

\begin{tabular}{|c|c|}
\hline Specific Gravity of tyre chips & $1.14 \%$ \\
\hline Water absorption of tyre chips & $4 \%$ \\
\hline
\end{tabular}

\section{Coarse aggregate}

As the comparison is made with tyre chips and fly ash brick chips the similar size is taken for the coarse aggregate also. The coarse aggregate of size passing through $12.5 \mathrm{~mm}$ sieve and retains on $10 \mathrm{~mm}$ sieve was taken [4]. Flakiness and Elongation properties of coarse aggregates were found.The properties of coarse aggregate [10] is showed in the table 3 .

Table3.Coarse aggregate properties

\begin{tabular}{|c|c|}
\hline $\begin{array}{c}\text { Specific gravity of coarse } \\
\text { aggregate }\end{array}$ & 2.6 \\
\hline $\begin{array}{c}\text { Water absorption of coarse } \\
\text { aggregate }\end{array}$ & $2.5 \%$ \\
\hline Crushing value of aggregate & 12.18 \\
\hline
\end{tabular}

Fly ash brick chips

Fly ash brick chips of size passing through $12.5 \mathrm{~mm}$ sieve and which retains on $10 \mathrm{~mm}$ sieve was taken as an alternate replacement material for coarse aggregate [5]. Basic tests for Fly ash brick chips are carried out at Laboratory [10] and material sizes are shown in table 4.

Table 4. Sizes of materials used

\begin{tabular}{|c|c|}
\hline Materials & Size (mm) \\
\hline Coarse aggregate & 10 \\
\hline Tyre chips & 10 \\
\hline Fly Ash Brick chips & 10 \\
\hline Clay Soil & 4.25 \\
\hline
\end{tabular}

\section{Test setup}

The Cylinder tank made of cast iron having height of $410 \mathrm{~mm}$ was used. It is shown in figure 2 and mould dimensions are shown in table 5 . The wall thickness of the tank was $3 \mathrm{~mm}$ and diameter of the tank is $250 \mathrm{~mm}$. The scaling factor used in test model was $1 / 10$. The diameter of the stone column is $45 \mathrm{~mm}$ with the height of $270 \mathrm{~mm}$ placed at the center of the tank corresponding to L/D ratio(Length of the column to diameter of the column equal to 6). The load was given through the proving ring at a constant rate of $25 \mathrm{~mm} / \mathrm{min}$ vertically over the stone column by placing a circular disc over the column for uniform distribution of load. 


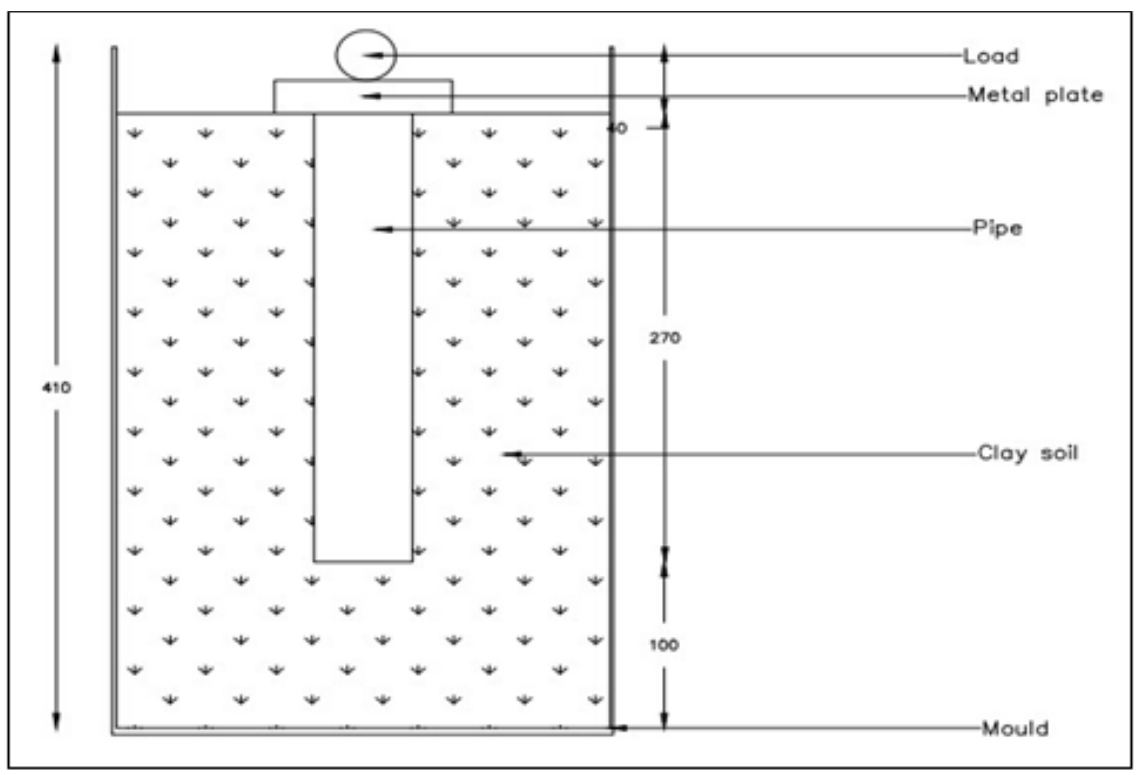

Figure 2. Mould

Table 5. Mould dimensions

\begin{tabular}{|c|c|}
\hline \multicolumn{2}{|c|}{ Mould Dimensions in mm } \\
\hline Height & 410 \\
\hline Inner diameter of mould & 250 \\
\hline Outer diameter of mould & 256 \\
\hline Thickness of mould & 3 \\
\hline Material of mould & Cast iron \\
\hline
\end{tabular}

\section{Formation of clay bed}

The empty tank is first filled by grease around the inner wall in order to reduce the friction between the clay and cylinder. The water content of soft clay is maintained properly and periodical test was carried.

The soft clay is placed as layers in tank [11] and compacted manually by hands to ensure the even spread of soil inside the tank without Air traps. The clay is filled up to certain height in the tank.

\section{Formation of stone column}

The centre of the tank is marked in proper position so that Load can be distributed uniformly. The column is designed in such a way that it can reused. The material used for the pipe column is Polyvinyl chloride (PVC) of diameter $45 \mathrm{~mm}$ and thickness of $3 \mathrm{~mm}$ diameter.

The PVC pipe is applied by greases on both sides for friction purpose. At base $100 \mathrm{~mm}$ is filled with clay. Then the PVC Pipe column is placed at the centre and tyre chips are placed layer by layer with well compaction with great care to ensure proper compaction [12].

The pipe is fully filled and surrounded with clay uniformly up to height of $270 \mathrm{~mm}$ and the pipe was slowly taken out at each layer when outside clay soil is filled uniformly and its behavior is 
notes [13]. This procedure is carried out for other proportions of tyre chips, fly ash aggregates and coarse aggregates [14].

\section{Procedure for Testing}

The apparatus is placed on the testing machine for testing. The Load is given at center of the column. The $\mathrm{L} / \mathrm{D}$ ratio considered for the test is 6 .

The load was given and respective settlement values are noted[3] shown in figure 3.

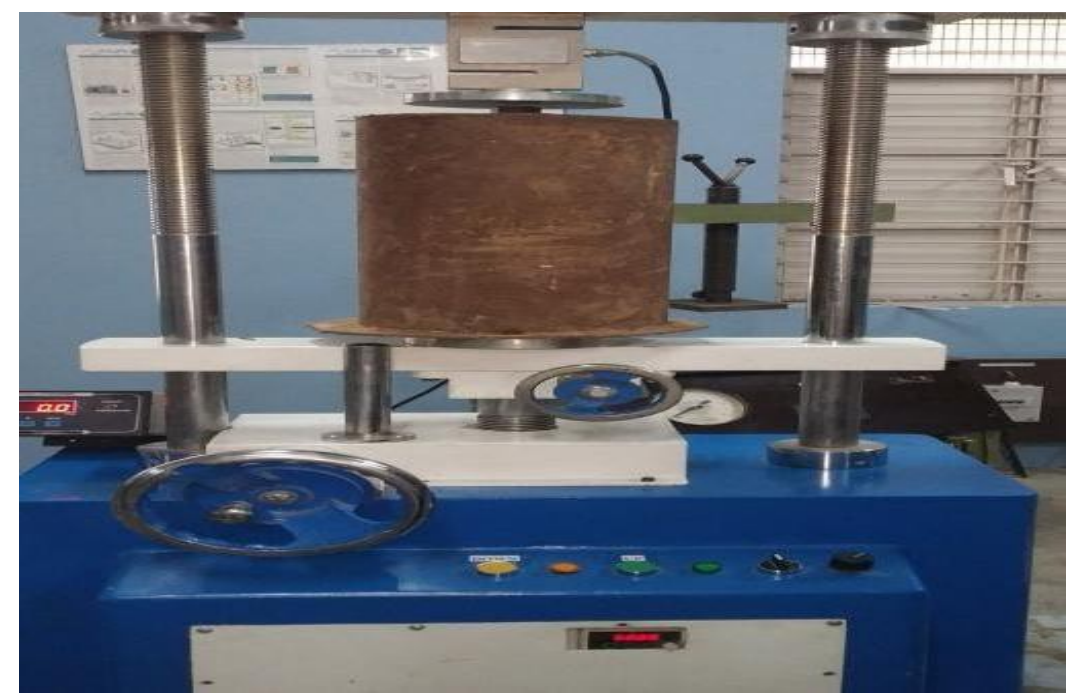

Figure 3. A shows the loading of clay soil through hydraulic jack with constantly increasing loading.

\section{Result and discussion}

The behavior of Tyre chips, Stone Aggregate and Fly ash brick chips are compared and shown in following bar chart. From the chart it is noted that the load settlement behavior of the proportion is not in linear form. All the test were carried out at carried the same compacted density of 5-7 $\mathrm{KN} / \mathrm{m} 3$.The graph of all proportions shows various rates of settlement with respect to load. The proportions are made in order to reuse the waste materials in construction field. As a result of using coarse aggregate as a column filler it gives raise in cost which does not leads to efficiency.

The graph shows the settlement rate of each proportion. It helps to compare the proportions for better usage in construction. On comparison 50\% proportions shows good capacity of load bearing. But on specific $75 \%$ coarse and $25 \%$ tyre chips shows high load bearing capacity along with cost efficiency which make the soft clay more stable than other composition. It is noted that the mechanical properties of coarse and tyre chips with proper proportion shows a better bearing capacity of load as they could withstand for higher load. The crushing properties of coarse and tyre seems to hold good for the soft clay soil.80\% of combinations of Coarse Aggregate (80\%) with Fly Ash brick chips $(20 \%)$ shows that the proportion could hold load better but not as of $75 \%$ proportion. 


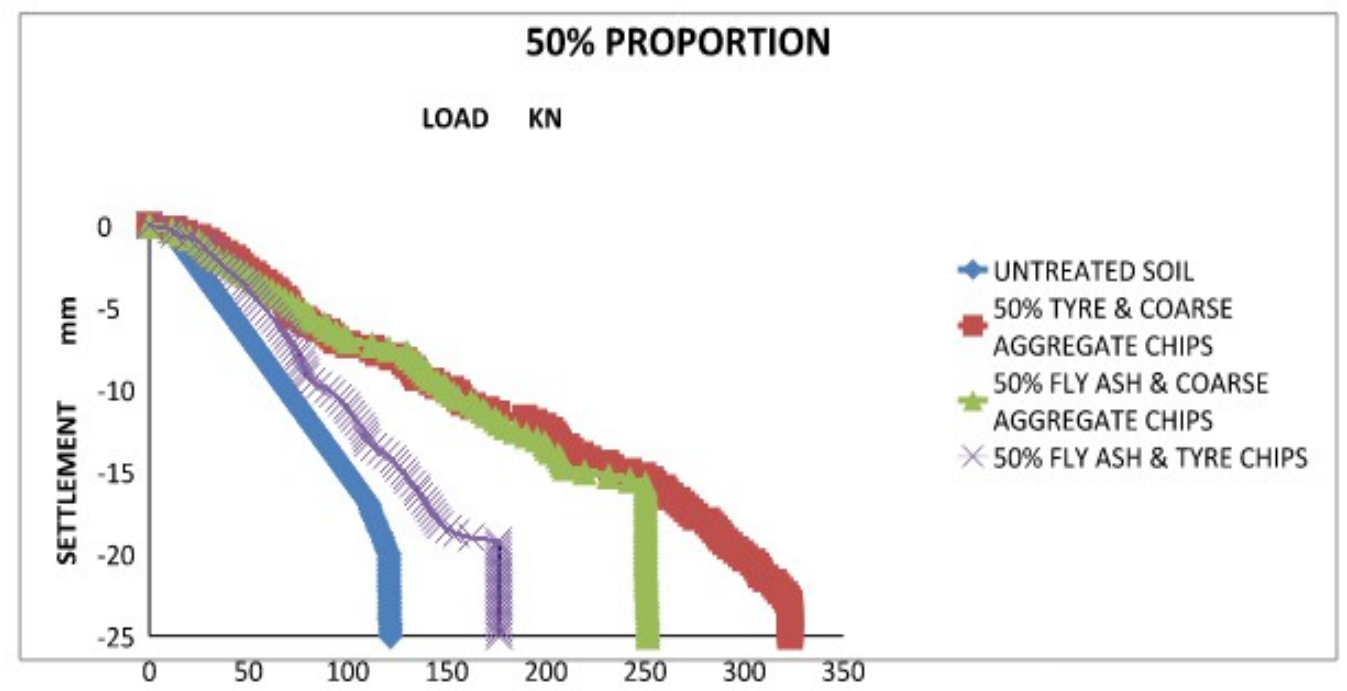

Figure 4. Load vs Settlement for 50\% proportion

The above figure 4 shows the various combinations of $50 \%$ proportions such as $50 \%$ tyre chips and coarse aggregate, 50\%fly ash and coarse aggregate, 50\% fly ash and tyre chips. The graph gives a clear view of comparison between three proportions with untreated soil with respect to load and settlement. It shows the load increment given to the column and respective settlement rate of the proportion.

From the graph it is inferred that the rate of settlement of coarse aggregate with fly ash proportion withstand high load than fly ash with coarse aggregate proportion. The untreated soil has lesser strength to bear the load given to it due to its nature. The proportion of fly ash and tyre chips fails sooner than other proportion since the fly ash initially crushes faster than coarse aggregate. Along with tyre chips, fly ash combination shows greater settlement at initial stage itself.

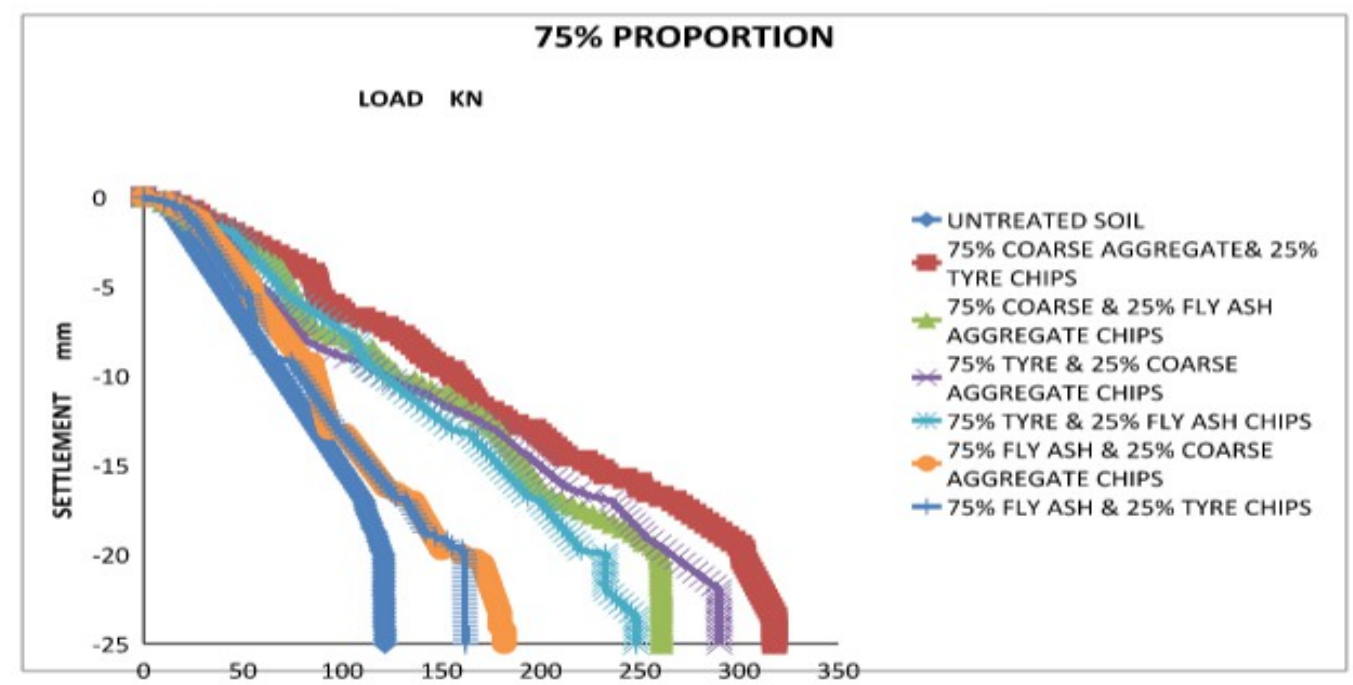

Figure 5. Load vs Settlement for 75\% proportion

The figure 5 shows the various combinations of $75 \%$ proportions such as Tyre chips (75\%) with Coarse Aggregate (25\%), Coarse Aggregate (25\%) with Fly Ash brick chips (75\%), Aggregate 
(75\%) with Fly Ash brick chips (25\%), Tyre chips (25\%) with Fly Ash brick chips (75\%), Tyre chips (75\%) with Fly Ash brick chips (25\%) and Tyre chips (25\%) with Coarse Aggregate (75\%).

The graph gives a clear view of comparison between three proportions with untreated soil .It shows the load increment given to the column and respective settlement rate of the proportion. From the graph it is inferred that the rate of settlement of coarse aggregate with tyre chips proportion withstand high load than other proportions. The untreated soil fails soon as it could not carry load further.

From this it is noted that the mechanical properties of coarse and tyre chips with proper proportion shows a better bearing capacity of load as they could withstand for higher load. The crushing properties of the coarse and tyre seems to hold good for the test shown in figure 6 .

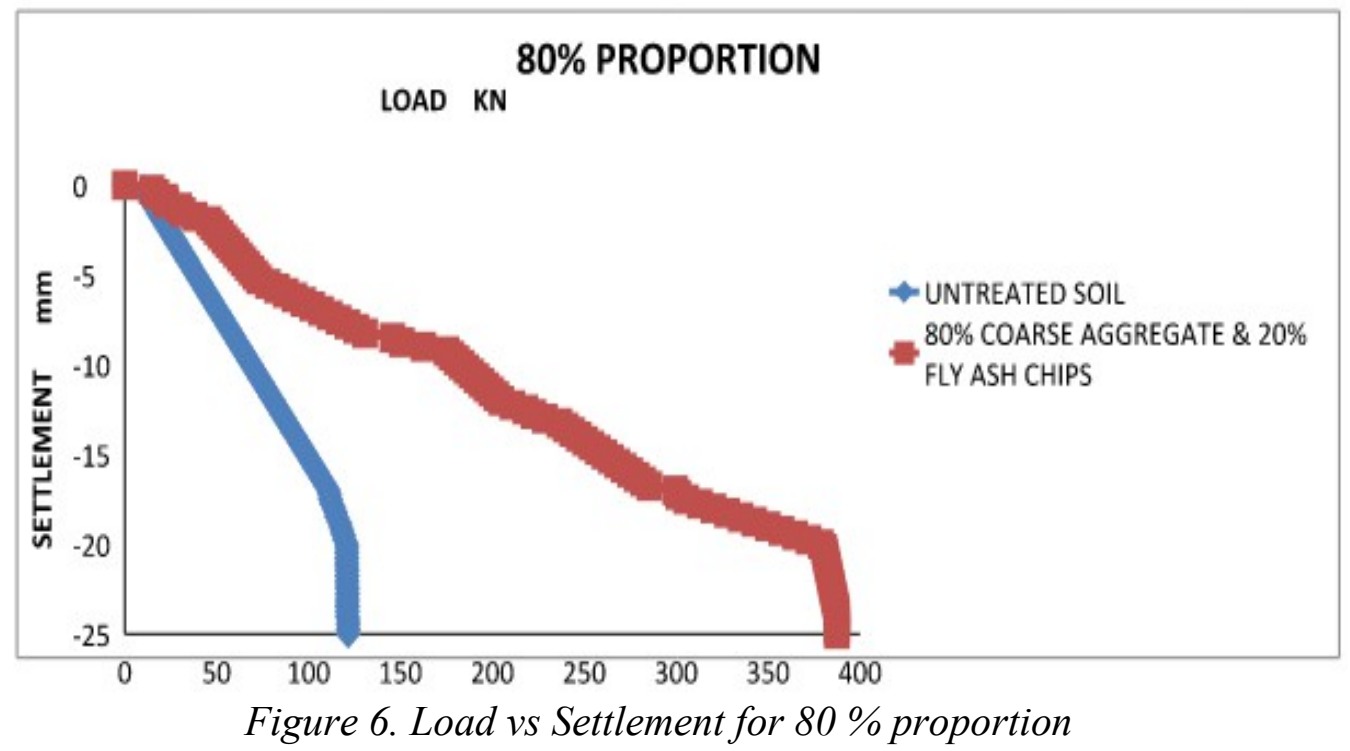

The graph shows the combinations of $80 \%$ of combinations of Coarse Aggregate (80\%) with Fly Ash brick chips $(20 \%)$. The graph gives a clear view of comparison between three proportions with untreated soil and the proportion. It shows the load increment given to the column and respective settlement rate of the proportion.

From the graph it is inferred that the rate of settlement of coarse aggregate and fly ash chips is higher than the untreated soil loading capacity shown in figure 6 . The untreated soil fails since the soil has lesser strength to bear the load given to it due to its nature.

The figure 7 shows the combinations of $100 \%$ proportions such as $100 \%$ tyre chips, $100 \%$ coarse aggregate, $100 \%$ fly ash chips. The graph gives a comparison between three proportions with untreated soil .It shows the load increment given to the column and respective settlement rate of the proportion. From the graph it is inferred that $100 \%$ coarse aggregate carries approximately $420 \mathrm{KN}$ load than other proportion. When untreated soil is loaded it gets settled at minimum load due to its property. Next to coarse aggregate, the tyre chips of considered size prove to hold good to withstand load up to certain level. 


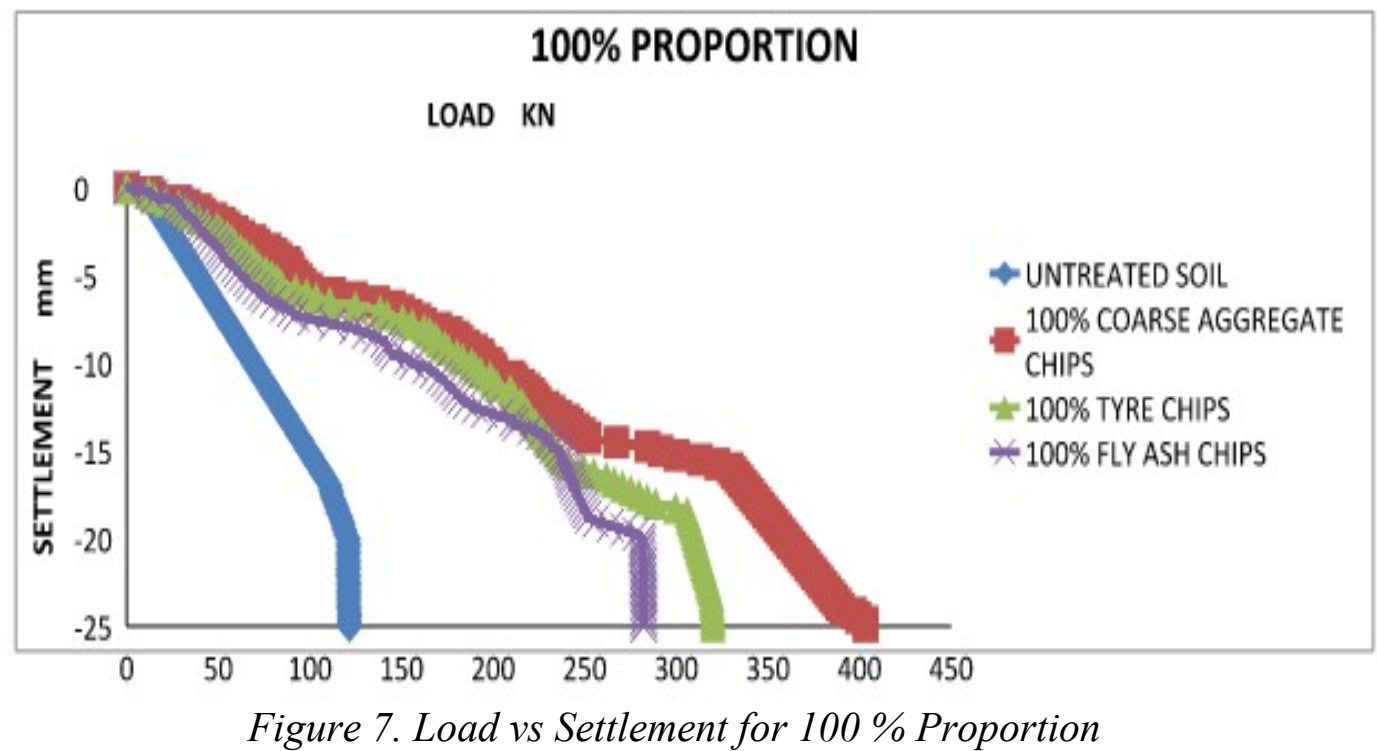

\section{Conclusion}

From overall Model test it is observed and noted that the combination $75 \%$ tyre chips and $25 \%$ coarse aggregate when compared with other combination such as 50\% tyre chips and 50\% coarse aggregate, $75 \%$ coarse aggregate and $25 \%$ tyre chips, $100 \%$ tyre chips, $100 \%$ coarse aggregate chips, $100 \%$ fly ash brick chips shows a better result and Load Carrying Capacity with lesser settlement rate. From the inferred result, replacement of stone aggregate with specific range will reduce the construction cost and can enhance the strength and settlement capacity of the column [15]. Thus usage of tyre chips does not affect the quality of groundwater and pollute the environment. It can be a better way to reduce the waste material. The graph and the settlements values are based on the test carried out in the laboratory with the objective of reusability of waste materials in construction practice.

\section{References}

[1] A. Al-Tabbaa, O. Blackwell, S. Porter, An investigation into the geotechnical properties of soil-tyre mixtures, Environmental technology. 18 (1997) 855-860.

https://doi.org/10.1080/09593331808616605

[2] D. Tapas, S. Baleshwar, Benefits and impacts of scrap tyre use in geotechnical engineering, J. Environ. Res. Develop. 7 (2013) 1262-1271.

[3] S. Malarvizhi, K. Ilamparuthi, Load versus settlement of clay bed stabilized with stone and reinforced stone columns, Proceeding of the 3rd Asian Regional Conference on Geosynthetics, GEOASIA Seoul, Korea, 2004. pp. 322-329.

[4] S. Verma, S. Akhtar, S. Shrivastava, Assessment of Particles of Varied Soil By Grain Size Analysis-A Case Study in Jabalpur MP, International Journal of Engineering Research and Application. 7 (2017) 32-37. https://doi.org/10.9790/9622-0707093237

[5] A. Sridharan, H. Nagaraj, Plastic limit and compaction characteristics of finegrained soils, Proceedings of the institution of civil engineers-ground improvement. 9 (2005) 17-22. https://doi.org/10.1680/grim.2005.9.1.17 
[6] S.-A. Tan, T.-S. Tan, L.C. Ting, K.-Y. Yong, G. Karunaratne, S.-L. Lee, Determination of consolidation properties for very soft clay, Geotechnical Testing Journal. 11 (1988) 233-240. https://doi.org/10.1520/GTJ10653J

[7] T. Kokusho, Y. Yoshida, Y. Esashi, Dynamic properties of soft clay for wide strain range, Soils and Foundations. 22 (1982) 1-18. https://doi.org/10.3208/sandf1972.22.4_1

[8] H. Moo-Young, K. Sellasie, D. Zeroka, G. Sabnis, Physical and chemical properties of recycled tire shreds for use in construction, Journal of Environmental Engineering. 129 (2003) 921-929. https://doi.org/10.1061/(ASCE)0733-9372(2003)129:10(921)

[9] A. Priyadarshee, D. Gupta, V. Kumar, V. Sharma, Comparative study on performance of tire crumbles with fly ash and kaolin clay, International Journal of Geosynthetics and Ground Engineering. 1 (2015) 1-7. https://doi.org/10.1007/s40891-015-0033-3

[10] H. Liu, S.K. Banerji, W.J. Burkett, J. Van Engelenhoven, Environmental properties of fly ash bricks, World of Coal Ash, USA, (2009).

[11] R. Shivashankar, M.D. Babu, S. Nayak, V. Rajathkumar, Experimental studies on behaviour of stone columns in layered soils, Geotechnical and Geological Engineering. 29 (2011) 749. https://doi.org/10.1007/s10706-011-9414-0

[12] A. Zahmatkesh, A. Choobbasti, Settlement evaluation of soft clay reinforced by stone columns, considering the effect of soil compaction, International Journal of Research and Reviews in Applied Sciences. 3 (2010) 159-166.

[13] W.-S. Bae, B.-W. Shin, B.-C. An, J.-S. Kim, Behaviors of foundation system improved with stone columns, The Twelfth International Offshore and Polar Engineering Conference, International Society of Offshore and Polar Engineers, 2002.

[14] R. Ayothiraman, S. Soumya, Model tests on the use of tyre chips as aggregate in stone columns, Proceedings of the Institution of Civil Engineers-Ground Improvement. 168 (2015) 187-193. https://doi.org/10.1680/grim.13.00006

[15] J. Castro, M. Karstunen, N. Sivasithamparam, Influence of stone column installation on settlement reduction, Computers and Geotechnics. 59 (2014) 87-97. https://doi.org/10.1016/j.compgeo.2014.03.003 